his return to Holland wrote the monographs on the two families of the Gorgonacea-the Chrysogorgiidæ and Primnoidæ-collected by the Expedition. The care he took in the description of the species, his skilful illustrations and his references to type specimens, which he examined whenever available, have rendered these monographs of extraordinary value and interest. They are still the standard works on the subject. After the completion of his work on these cœlenterates, he turned his attention to the study of the skull of reptiles and published his first paper on the morphology of the columella bone before he left Amsterdam. In 1904 he migrated to Germany and became a Privat Dozent and later an assistant professor in the University of Giessen, and during the following ten years he produced several papers on the skulls of recent and fossil reptiles bearing on what he called "Das Streptostylie Problem", or the mobility (kinetism) of the bones of the jaws on those of the brain case.

At the outbreak of the Great War, Versluys remained in Germany, but after the occupation of Belgium by the German army he was appointed a professor in the Flemish University in Ghent and remained there until the Armistice. Returning to Holland, he made a home in the beautiful town Hilversum and there he began a study of another subject, which he called "Das Limulus problem". Working in collaboration with R. Demoll, of Munich, a number of papers were published on the appendages and other structures of recent and extinct Arachnoidea, especially of Limulus and the other Merostomata.

The general conclusions reached by these authors were startling in their originality but have not been accepted by most of the zoologists in Great Britain. They suggested that the evolution of Limulus was on lines exactly the reverse of those suggested by Sir Ray Lankester in his well-known essays on this subject. Limulus was derived, according to their view, not from an aquatic but from an air-breathing, tracheate ancestry; and, moreover, that even the Crustacea are descended from a remote terrestrial group of animals of which Peripatus is the only living representative.

After a few years in Holland, Versluys accepted the position of professor in the University of Vienna and remained there until his death. I have not been able to find any record of his original work in this last period of his life, except an abstract of a paper he read at the British Association meeting in 1934, on the distribution of the Primnoidæ with reference to the Wegener hypothesis.

He leaves a widow and three children. SydNey J. Hrckson.

\section{Eng.-Commander J. J. Walker}

ThE death on January 12 of Eng.-Commander James John Walker will be deeply regretted by very many British naturalists, especially by students of his favourite insects-Coleoptera and Lepidoptera.

Elected in 1878, Walker had been for some years the senior fellow of the Royal Entomological Society of London, and was president in 1919 and 1920, his two addresses being on "The Fringes of Butterfly Life" and "Some Aspects of Insect Life in New Zealand" (Proc., 1920 and 1921). Two of his papers in the Transactions of 1890 and 1895 dealt with Lepidoptera from the Straits of Gibraltar and the butterflies of Hong Kong, respectively, while the Proceedings (1907-31) includes many of his interesting notes on British and a few on foreign insects. The vast majority of his observations made on voyages and at home appeared, however, in the Entomologist's Monthly Magazine, of which he became editor in 1904, on the death of Robert MeLachlan. The first of his notes and papers in this excellent journal-more than three hundred in number-appeared in 1872, and the last, dated December 20, 1938, less than a month before his death, was published in January. It records the more interesting of fully three hundred species of Coleoptera which he had observed in about thirty acres of meadow and cultivated, land between his house and the River Cherwell.

Among Walker's papers were many on interesting subjects which he always kept in mind and added fresh records as they came to light. Such were his notes in 1908, 1911, 1912, 1928 and 1931, on immigrant insects which invaded Great Britain; in 1922, on butterflies which have reached Iceland and on the Lepidoptera of North Atlantic islands; in 1931, on insects at sea; in 1914, 1915 and 1928, on the Monarch butterfly, Danaus plexippus, and its migrations. Among the many British localities from which he published records the most frequently named are, Isle of Sheppey, Sheerness, Chatham, Kent, Portland, New Forest and especially Oxford, which became his home in May 1904. The honorary M.A. was conferred on him by the University in the following year.

Walker was a constant visitor to the Hope Department of Entomology in the University Museum, Oxford, where he gave immensely valuable help in describing, arranging and recording the historic collections. $\mathrm{He}$ joined the Ashmolean Natural History Society in 1904, became president in 1913-14 and from 1911 onwards was editor of the Proceedings, in which he published (1907-30) a valuable list of Oxford Coleoptera with supplements; also twenty-three interim reports (1911-38), the last four including Lepidoptera in addition to Coleoptera.

The above is a very condensed account of some of the chief publications of one who, in spite of his great age-eighty-seven years-retained to the very end his wonderful memory, keen interest and the never-failing desire and ability to help his brothernaturalists.

E. B. Poulton.

\section{Prof. Albert Sauveur}

Prof. Albert SAUVEur, emeritus professor of metallurgy in Harvard University, whose death occurred recently in Cambridge, Mass., was a Belgian by birth, but was long known as the leading teacher of metallurgy in the United States.

Born at Louvain in 1863, he studied in the School of Mines of Liège, and later crossed the Atlantic to enter the Massachusetts Institute of Technology, 